\title{
Chapter 5 \\ Disrupted, Ruptured, and in Between: Ruins of Schooling and Utopian Learning Society
}

\author{
Dae Joong Kang
}

\section{Abbreviations}

$\begin{array}{ll}\text { GIE } & \text { Gyeonggi Institute of Education } \\ \text { KERIS } & \text { Korea Education and Research Information Service } \\ \text { OECD } & \text { Organisation for Economic Co-operation and Development } \\ \text { UNESCO } & \text { United Nations Educational, Scientific and Cultural Organization }\end{array}$

\subsection{Introduction}

Education is one of the areas most affected by the coronavirus disease (COVID-19) pandemic. Schools and universities worldwide closed for a time, and almost all students had to stay at home. Distance teaching and learning suddenly became the new normal. Many countries adopted flexible learning strategies using various information and communication technologies after schools shut down (Reimers and Schleicher 2020; United Nations 2020; Wagner and Warren 2020). In the past, we have seen many policy documents that advocate education reform with new technology. In many cases, the reform measures were only partially implemented and, for a long time, remained largely on paper. The COVID-19 pandemic made technology-enhanced education a reality within just a year, especially in technologically savvy countries like the Republic of Korea, for which this was a first in its history.

My two daughters, one in elementary school and another in middle school, started their "new normal" school days by opening their laptops at home and logging into

\footnotetext{
D. J. Kang $(\varangle)$

Department of Education, Seoul National University, Seoul, Republic of Korea

e-mail: kdj@snu.ac.kr
} 
their school's learning management system. Although they own personal laptops, they never used them for school assignments before the pandemic. The process was somewhat chaotic. They had to use a synchronous video-chatting application, watch video clips and slides that their teachers uploaded or relayed, and leave a message on a board instead of interacting directly with their classmates. My two daughters had to learn how to adapt to this technology-assisted educational environment at home. As a university professor, I also taught all courses with Zoom and Moodle-based learning management systems. Using this advanced technology was the only viable option to continue teaching and learning since COVID-19 kept us away from face-to-face interaction. Though it is very tough to effectively implement distance teaching and learning in a country with more than 8 million students, the Ministry of Education took this opportunity to shift its entire education system toward technology-assisted blended learning.

COVID-19 has significantly disrupted traditional learning, teaching, and working in the education field (Crawford et al. 2020; Lopes and McKay 2020; United Nations 2020). Being forced to replace traditional face-to-face physical classroom teaching with online and distance learning on an unprecedented scale has significant implications for schooling and education in the future. Is this the real beginning of a new era in education that is challenging the centuries-old traditional school system? Can this new normal be the better normal in education? Before the pandemic, the concept of the learning society had been circulating for more than 50 years as the future of education reform. Learning is considered a lifelong endeavor beyond the early stage of formal schooling, and as a life-wide phenomenon both in and out of school.

Technological development is vital to this change in education. There has been a strong consensus that the learning society is the guiding concept to imagine and concretize the new education system. Would the COVID-19 pandemic turn out to be the watershed moment in history to realize the much-hyped learning society? It seems the challenges caused by COVID-19 will finally bring about educational change as predicted, with the fruition of the concept of a learning society.

In this paper, I sum up how the education system in the Republic of Korea and around the world was disrupted by COVID-19, and how countries responded to the pandemic. I will remind the reader that the school-centered education system has been ruptured by new socioeconomic demands and technological developments even before the pandemic, giving birth to the discourse of lifelong learning and the learning society. In conclusion, I will discuss ways to take advantage of the pandemic to move toward the era of the learning society.

\subsection{Disrupted}

COVID-19 caused extraordinary worldwide disruption in education. In mid-April 2020, 1.58 billion children and young people in more than 190 countries stopped attending school-approximately $94 \%$ of the entire student population worldwide 
(United Nations 2020). Not many people expected this huge-scale disruption when COVID-19 was first reported in the People's Republic of China. Although children and adolescents' mortality rate from COVID-19 was not high, clearly the current education system was most vulnerable to virus transmission.

In the Republic of Korea, the government did not expect a whole school system lockdown when the first COVID-19 case was reported on 20 January 2020. The Ministry of Education first focused on quarantining the returning college students from the People's Republic of China, specifically from Wuhan, the epicenter of the virus at the time. However, when COVID-19 spread in Daegu by the end of February 2020, things suddenly changed. The start date of the schoolyear, 2 March, was postponed for a week at first. It was postponed again to $23 \mathrm{March}$, then to 6 April. Schools finally opened on 9 April but online. It was the first time in the history of the Republic of Korea that schools opened online in April. When COVID-19 was contained in May and June, students could finally go to school, though only a third to two-thirds of the student were allowed each day. Thus, online learning continued. Colleges and universities also postponed the start of the semester and maintained online distance learning throughout the semester.

Around the world, school shutdowns and rapid transitions to online learning revealed poor digital conditions. Access to digital devices and high-speed internet is unequal from household to household and country to country. Among those who took the 2018 Programme for International Student Assessment (PISA) test in Latin America and the Caribbean region, only $61 \%$ had access to a computer at home (ECLAC-UNESCO 2020). Only 36\% of the residents of lower- and middle-income countries have access to the internet (Vegas 2020). Even the wealthier and technologically advanced countries were no exception. In Europe, $6.9 \%$ of the children cannot access the internet (Lancker and Parolin 2020). All the 46 members of the Organisation for Economic Co-operation and Development (OECD) and partner countries had closed their schools from 7 to 19 weeks by the end of June 2020. This meant that most of the countries that participated in the OECD's 2018 PISA were not ready for online learning and teaching (Schleicher 2020).

Many countries struggled to cope with the disruption caused by COVID-19. Building a smart school that fits the digital learning environment was an essential policy direction in the Republic of Korea even before the COVID-19 crisis. However, an elementary schoolteacher recalled in an interview, "A year ago I couldn't help but laugh when the Ministry of Education talked about using artificial intelligence in schools." The teacher continued that until February 2020 there was no Wi-Fi in classrooms. Commercial e-mail services such as Gmail or Microsoft Outlook were banned in school. No one could use a cloud service in school at all. The school attended by the "ARMY", the fans who support the world-class K-pop group BTS through social media networks, did not even have Wi-Fi. ${ }^{1}$

The German situation was not so different from that of the Republic of Korea. In a survey on the early career teachers' adaptation to online teaching, König

\footnotetext{
${ }^{1}$ Personal communication. This interview was conducted for a Korean book entitled COVID-19 Awakens Korean Education (2020, Knowledge Smith).
} 
et al. (2020) found that even the native digital generation of teachers are not well equipped with the necessary digital skills. It is because "many schools lag behind the expected information and communication technology (ICT) transformation process in educational systems" (König et al. 2020, p. 618). The COVID-19 pandemic was a game-changer in this regard. As another Korean teacher described the situation, "COVID-19 grabs schools by the collar and drags it toward digital technology".

Still, it was tough to adapt to the challenging situation. According to a joint survey of the United Nations Educational, Scientific and Cultural Organization (UNESCO), United Nations Children's Fund, and World Bank on COVID-19 response from April to mid-June 2020, only about half of the surveyed countries provided teachers with additional training on distance learning. Among primary school teachers, $81 \%$ had the minimum required qualifications, and among secondary school teachers, $86 \%$, according to data published by the UNESCO Institute for Statistics, International Task Force on Teachers, and the Global Education Monitoring Report (UN News 2020).

The Republic of Korea is one of the most successful countries to cope with the disruption. Online and distance education very quickly became the new normal. A survey by the Korea Education and Research Information Service (KERIS) ${ }^{3}$ in Kye et al. (2020); and a survey by the Gyeonggi Institute of Education (GIE) ${ }^{4}$ in Baek and Jung (2020), show some critical aspects of the educational response to the pandemic in the country. According to the KERIS survey, (i) $66 \%$ of the teachers considered themselves to be ready for distance teaching; (ii) only $14.8 \%$ of the teachers used real-time online teaching that allows synchronous interaction with students; and (iii) $78.4 \%$ of the teachers used asynchronous methods to give out learning materials and assignments. This was also observed in the GIE survey. On the question on how the teachers are conducting online classes, $33.6 \%$ of them assigned work and gave feedback, $31.7 \%$ created their own videos of lessons, and $29.2 \%$ used pre-produced videos. Only $5.5 \%$ conducted real-time interactive lessons. The fact that a relatively small number of teachers used the real-time teaching method shows that online teaching during the COVID-19 crisis focused on knowledge transfer. The advantages of online classes, such as personalized instruction or various interaction techniques, have not been much utilized.

The KERIS survey shows only that half of the parents were satisfied with distance education. Among primary school parents, 54\% were satisfied, and 48\% for secondary school parents. About $80 \%$ of primary school parents responded that they helped with their children's learning while only about $42 \%$ of secondary school parents did. This reflects how elementary school parents place a high priority on helping their children at home. The academic achievement gap among students seems

\footnotetext{
${ }^{2}$ Footnote 1.

${ }^{3}$ The KERIS survey was conducted nationwide from 29 July to 1 August 2020, right after the first semester. A total of 857,389 people participated in the survey including 51,021 teachers; 213,012 primary school students; 212,434 secondary school students; 213,012 primary school parents; and 167,910 secondary school parents.

${ }^{4}$ The GIE survey was conducted on 11-16 June 2020 with 28,445 teachers; 433,591 parents; and 200,085 students in Gyeonggi-do, the largest province in the Republic of Korea.
} 
to have widened, as indicated by $79 \%$ of the teachers in the KERIS survey who attribute differences in the students' capability for self-directed learning $(64.92 \%)$, parental support $(13.86 \%)$, and difficulties in communication between the teacher and the student $(11.6 \%)$ as possible reasons. At a focus group interview with teachers in the GIE survey, a high school teacher talked about the results of the schoolwide semester final examination.

We did not have the normal distribution of the student's scores. Instead, the final exam result showed a reverse pattern: $\mathrm{U}$-shaped. Analyses showed that students who are good at self-directed learning repeat learning with the materials uploaded by the teacher; thus, they learn thoroughly.... There are almost no students who scored between the $40 \mathrm{~s}$ and the $70 \mathrm{~s}$ [out of 100 points; above 60 is considered a passing score] while the number of students with scores in the $20 \mathrm{~s}$ increased significantly. (Baek and Jung 2020, p. 37)

As most countries focused on the urgent matter of containing the virus to prevent a health care system failure and boost businesses and the economy, the long-term consequences of school closures seemed to be a less urgent issue. However, it is a serious agenda in the long run. Above all, it is certain that school closures will have a long-term impact on students' mental health and psychological stability (Lee 2020; Radwan et al. 2020). The disruption of schooling has a lifetime impact on personal income and causes a decline in gross domestic product. Hanushek and Woessmann (2020) predicted that the learning loss caused by the school closures in the first half of 2020 might result in "something on the order of 3\% lower career earnings" (Hanushek and Woessmann 2020, p. 6) for the typical current student. This economic loss is undoubtedly more significant for low-achieving students who lack the spontaneous motivation to learn, and for students from disadvantaged households who do not have enough direct support from their family members.

It was predicted that schools had returned to 2019 performance levels soon after September 2020. However, that did not happen. The long-term effects of school closures will accumulate until schools return to their pre-epidemic state. The pandemic exacerbates the existing inequality (Blundell et al. 2020; Lancker and Parolin 2020). Hanushek and Woessmann argue, "the future impact of past and future learning losses need to be considered when it comes to the design of mixed in-person and home learning and when classes are potentially cancelled again locally or regionally due to newly occurring infections" (Hanushek and Woessmann 2020, p. 12).

\subsection{Ruptured}

In a landmark UNESCO report, Learning to Be, Faure et al. (1972) report that "[F]or the first time in history, education is now engaged in preparing (people) for a type of society that does not yet exist. The change can be easily explained if the relative stability of past societies is compared with the accelerated development of the contemporary world. At a time when the mission of education should be to train 'unknown children for an unknown world', the force of circumstances demands that 
educationists do some hard thinking, and that in so doing they shape the future" (Faure et al. 1972, p. 13).

Compared to the Spanish flu in the 1920s, we can continue many activities during the COVID-19 pandemic thanks to new technologies that were nonexistent a century ago. The digital transformation of contemporary society is at the heart of this technological development. At the same time, technological development is a source of instability in education, as the Faure et al. (1972) report succinctly points out. The ongoing fourth industrial revolution or Industry 4.0, along with artificial intelligence technology, is not an exception. Development in technology brings about a profound challenge in education. I would like to specifically dwell on two facets of such a challenge.

\subsubsection{An Institutionalized Education System Is Not Enough}

The Faure report carefully examines the changes the world would be faced with in the latter half of the twentieth century. It points out that the pace of the development of new technologies creates challenging conditions for the education system. The report exemplifies the decreasing time gap between discovering a scientific principle and applying it on a large scale. There was a difference of 112 years between discovering the principle of photography in 1727 and its practical application in 1839. Compare this with the scientific discovery of the solar cell in 1953 and its actual production today of only 2 years. The same goes for advances in the speed of human travel. From walking speed for hundreds of thousands of years, humans by the end of the nineteenth century could travel at a speed of $140 \mathrm{~km}$ per hour thanks to automobiles. In the mid-twentieth century, jets made it possible to move ten times faster than a car. In the early $1970 \mathrm{~s}$, astronauts traveled at a speed of 40,000 km per hour.

Therefore, the Faure report argues that it is impossible to train humans for the fast-changing world with only the institutionalized education system. Merely expanding school education is not enough to prepare for the future. The report recommends 21 principles for educational reform, the first of which is "Every individual must be in a position to keep learning throughout his life. The idea of lifelong education is the keystone of the learning society" (Faure et al. 1972, p. 181). It highlights the idea of the learning society up front.

In 1996, UNESCO put forward lifelong learning instead of lifelong education with the report Learning: The Treasure Within (Delors et al. 1996). Since then, 25 out of 28 UNESCO documents and/or publications include "lifelong learning" in their titles (Lee and Jan 2018, p. 378). Lifelong learning became a slogan of the new era. The Delors Report stresses the four types of learnings to prepare for the twenty-first century: (i) learning to know, (ii) learning to do, (iii) learning to be, and (iv) learning to live together.

Alheit and Dausien (2002) diagnose that lifelong learning since the 1990s has served as a signifier for restructuring the education system. They identify changes in the concept of work in a postindustrial society, changes in the role of knowledge in 
an information society, functional limitations of existing educational institutions, risk society, and reflective modernity as comprising the background of lifelong learning. Lifelong learning is the keystone for deciphering the wider social change and educational policy response. Lifelong learning is the driving force to restructure the school-centered education system. In addition to formal learning in schools, lifelong learning encompasses nonformal learning and informal learning.

Lifelong learning has been much criticized because it promotes the commercialization of knowledge while depreciating the value of public education. However, lifelong learning has certainly expanded our understanding of learning as something that happens in much broader areas of life than in a formal school setting. The concept of lifelong learning makes "nonformal, informal, and self-directed learning... visible as legitimate sites for learning" (Merriam and Baumgartner 2020, p. 77).

\subsubsection{The First and Second Education Revolutions}

Collins and Halverson (2018) call the transition from school-centered education to lifelong learning as the second educational revolution. They divide the education system into three distinct eras: (i) the apprenticeship era, (ii) the universal schooling era, and (iii) the new era of education for lifelong learning. The first educational revolution was the transition from apprenticeship to universal schooling. While the first educational revolution was made possible by Industry 4.0, technological development plays a vital role in the second educational revolution. They present eight dimensions of the two educational revolutions. Each dimension shows how the school-centered education system is ruptured in the societal transition to lifelong learning:

(i) First, responsibility for education is shifting from parents to the state, then back to parents and individuals. Education is customized to individual interests, needs, and abilities using ICT in the lifelong learning era.

(ii) Second, what people expect of education has shifted from social reproduction, to success of all, then to individual choice.

(iii) Third, the content has changed from practical skills to academic knowledge, then to learning how to learn.

(iv) Fourth, pedagogy has also changed from apprenticeship to didacticism, then to interaction. In lifelong learning, individualized interactions between instructors and learners and between learners and learners are essential.

(v) Fifth, assessing educational outcomes has shifted from observation to standardized tests, then to embedded assessment. As computer-assisted learning increases in the era of lifelong learning, the learner's achievement level is immediately confirmed and prescribed accordingly.

(vi) Sixth, the location of education has moved from home to school, and now to anywhere. The school's monopoly on education is crumbling in the era 
of lifelong learning. The knowledge and information necessary for learning can now be obtained anywhere due to the rapid development of ICT.

(vii) Seventh, the character of educational culture has also changed from adult to peer, then to mixed-age. With the advent of lifelong learning, anyone can learn anytime and anywhere, forming an educational culture of groups consisting of varied ages and generations.

(viii) Eighth, the educational relationship has changed from a personal bond with familiar figures such as parents, relatives, or villagers to authoritative figures such as teachers, then to computer-mediated interaction. As computer-aided education increases, educational relationships among those who share interests and needs are getting based on cooperation that is not face-to-face (Collins and Halverson 2018, pp. 85-96).

As the first educational revolution did not wholly remove apprenticeship, schools will also not disappear in the transition to the lifelong learning era. However, schools cannot but change intrinsically. It is possible that a yet-unknown system will emerge sooner or later. This will undoubtedly depend on digital technology. Governance over the education system will also change as learning ubiquitously spreads throughout life and society. The concept of the school district shows the current state of educational governance. A new one will be different, as the discourse of lifelong learning no longer equates education with schooling.

\subsection{Conclusions}

Every crisis makes existing problems worse while bringing up new challenges. The reports by the United Nations and Save the Children on COVID-19's impact on education point out that school education was already facing very formidable problems even before the pandemic (United Nations 2020; Wagner and Warren 2020). More than 258 million children were out of school, which is about one in six school-age population worldwide. Due to the pandemic, 8.5 million more students are expected to drop out.

The new challenge is to figure out how to take advantage of the crisis response toward realization of the learning society. The COVID-19 pandemic is a significant catalyst for people to think about what a learning society looks like. The widespread use of digital technology made the new normal in education possible despite some problems. In countries with advanced economies and technologies, digital transformation in education is occurring very quickly. A variety of local facilities and resources, not schools, were used for learning, such as "village learning circles" (Zacharia 2020) in India; and the "community hubs initiative" in San Francisco (CBS SF 2020). These are examples of policy responses to the crisis.

Holford and Jarvis (2000) classify the learning society discourse into four main versions: (i) futuristic, (ii) reflexive, (iii) consumer, and (iv) government-planned. They see the first version, the futuristic society, as an ideal learning society that 
is "a modern fulfillment of the Athenian ideal, made possible not by slavery but by modern machine" (Holford and Jarvis 2000, p. 644). It promotes the idea of extending public-funded education in every corner of the society beyond the school system to help everyone at every life stage gain access to learning to fulfill oneself. However, this version of the learning society is far from realization due to financial constraints.

At the moment, the learning society cannot but remain futuristic. The second version, the reflexive learning society, is where learning is treated as a kind of must-do thing to keep oneself abreast with the rapidly changing (post)modern world. The learning society in this version is not something for the future but what we have to deal with here and now in everyday life. The third version, the learning society as a consumer society, depicts the marketplace where information, knowledge, educational programs, and even traditional degrees can be consumed privately. Traditional schools and educational institutes are one of many providers in this widening market. Holford and Jarvis specify that the second and the third versions of the learning society are not designed by legislation, policy, or government financing, but that "it has simply arrived" (Holford and Jarvis 2000, p. 649). I consider these two versions of the learning society as spreading faster and wider due to the rapid technological development.

The fourth version of the learning society is where a government actively plans to stimulate and control learning in the society. Holford and Jarvis see this version as "the 'third way' to learning society" (Holford and Jarvis 2000, p. 649). The European Union has promoted this version of the learning society since the 1990s. Recently, the United Nations' Sustainable Development Goals (SDGs) have also embraced this type of learning society. The Incheon Declaration, an educational version of the SDGs, put up a slogan, Towards Inclusive and Equitable Quality Education and Lifelong Learning for All (UNESCO 2015). Many national governments around the globe take up this version as well. Every 5 years, the Ministry of Education of the Republic of Korea renews the Basic Lifelong Education Development Plan as required by the Lifelong Education Act to construct a learning society.

COVID-19 provides an opportunity to make creative and imaginative policy proposals, which can accelerate the realization of the learning society. Two years before the publication of the Faure report, Illich (1970) defined the components of a good education system. Though his idea carries important aspects of lifelong learning, it was probably considered utopian back then. In closing this chapter, I would like to invite the reader to contemplate on the words of Illich as we are in the middle of the second educational revolution toward the era of lifelong learning:

A good educational system should have three purposes: it should provide all who want to learn with access to available resources at any time in their lives; empower all who want to share what they know to find those who want to learn it from them; and, finally, furnish all who want to present an issue to the public with the opportunity to make their challenge known. Such a system would require the application of constitutional guarantees to education. Learners should not be forced to submit to an obligatory curriculum, or to discrimination based on whether they possess a certificate or a diploma. Nor should the public be forced to support, through a regressive taxation, a huge professional apparatus of educators and buildings which in fact restricts the public's chances for learning to the services the profession is willing to 
put on the market. It should use modern technology to make free speech, free assembly, and a free press truly universal and, therefore, fully educational. (Illich 1970, p. 91)

\section{References}

Alheit, A., and D. Dausien. 2002. The double face of lifelong learning: Two analytical perspectives on a silent revolution. Studies in the Education of Adults 34 (1): 3-22.

Baek, B.-B., and Jung, J. 2020. One month after the attendance, what makes school different? (In Korean) Issue paper. No. 2020-09. Suwon: Gyeonggi Institute of Education.

Blundell, R., et al. 2020. COVID-19 and inequalities. Fiscal Studies 41 (2): 291-319.

CBS SF. 2020. San Francisco launches new community hubs to provide in-person learning support for kids. September 14. https://sanfrancisco.cbslocal.com/2020/09/14/san-francisco-launchesnew-community-hubs-to-provide-in-person-learning-support-for-kids/. Accessed 24 September 2020.

Collins, A., and R. Halverson. 2018. Rethinking education in the age of technology: The digital revolution and schooling in America, 2nd ed. New York: Teachers College Press.

Crawford, J., et al. 2020. COVID-19: 20 countries' higher education intra-period digital pedagogy responses. Journal of Applied Learning and Teaching 3 (1): 9-28. https://doi.org/10.37074/jalt. 2020.3.1.7.

Delors, J., et al. 1996. Learning: The treasure within. Paris: United Nations Educational, Scientific and Cultural Organization.

ECLAC-UNESCO. 2020. Education in the time of COVID-19. Santiago: The Economic Commission for Latin America and the Caribbean (ECLAC) and the Regional Bureau for Education in Latin America and the Caribbean of the United Nations Educational, Scientific and Cultural Organization (OREALC/UNESCO Santiago).

Faure, E., et al. 1972. Learning to be: The world of education today and tomorrow. Paris: United Nations Educational, Scientific and Cultural Organization.

Hanushek, E.A., and L. Woessmann. 2020. The economic impacts of learning losses. Paris: Organisation for Economic Co-operation and Development.

Holford, J., and P. Jarvis. 2000. The learning society. In Handbook of adult and continuing education, ed. A.L. Wilson and E. Hayes, 643-659. San Francisco: Jossey-Bass.

Illich, I. 1970. Deschooling society. https://learning.media.mit.edu/courses/mas713/readings/DES CHOOLING.pdf.

König, J., D.J. Jäger-Biela, and N. Glutsch. 2020. Adapting to online teaching during COVID-19 school closure: Teacher education and teacher competence effects among early career teachers in Germany. European Journal of Teacher Education 43 (4): 608-622. https://doi.org/10.1080/ 02619768.2020.1809650.

Kye, B., et al. 2020. Analysis of experience and perception of the distance education in primary and secondary school after COVID-19 (in Korean). Edutech Trend. No. 10. Daegu: Korea Education and Research Information Service.

Lancker, W.V., and Z. Parolin. 2020. COVID-19, school closures, and child poverty: a social crisis in the making. The Lancet Public Health 5 (5): e243-e244. https://doi.org/10.1002/pam.22175.

Lee, J. 2020. Mental health effects of school closures during COVID-19. The Lancet Child and Adolescent Health 4 (6): 421.

Lee, M., and S.K. Jan. 2018. Lifelong learning policy discourses of international organisations since 2000: A kaleidoscope or merely fragments? In The Palgrave International Handbook on Adult and Lifelong Education and Learning, ed. M. Milana et al., 375-396. London: Palgrave Macmillan. 
Lopes, H., and V. McKay. 2020. Adult learning and education as a tool to contain pandemics: The COVID-19 experience. International Review of Education 66 (4): 575-602. https://doi.org/10. 1007/s11159-020-09843-0.

Merriam, S.B., and L. Baumgartner. 2020. Learning in adulthood: A comprehensive guide, 4th ed. San Francisco: Jossey-Bass.

Radwan, E., Radwan, A., and Radwan, W. 2020. The mental health of school students and the COVID-19 pandemic. Aquademia 4 (2): ep20020. https://doi.org/10.29333/aquademia/8394.

Reimers, F.M., and A. Schleicher. 2020. School disrupted schooling rethought: How the COVID-19 pandemic is changing education. Paris: Organisation for Economic Co-operation and Development.

Schleicher, A. 2020. The impact of COVID-19 on education: Insights from education at a glance 2020. Paris: Organisation for Economic Co-operation and Development.

United Nations Educational, Scientific and Cultural Organization (UNESCO). 2015. Education 2030: Incheon Declaration and framework for action for the implementation of Sustainable Development Goal 4. Ensure inclusive and equitable quality education and promote lifelong learning opportunities for all. Paris: UNESCO.

United Nations. 2020. Education during COVID-19 and beyond. Policy Brief. New York.

UN News. 2020. Reimagine education to achieve quality learning for all, UN and partners urge. October 5. https://news.un.org/en/story/2020/10/1074652. Accessed 24 September 2020.

Vegas, E. 2020. School closures, government responses, and learning inequality around the world during COVID-19. April 14. https://www.brookings.edu/research/school-closures-governmentresponses-and-learning-inequality-around-the-world-during-covid-19/. Accessed 24 September 2020.

Wagner, E., and H. Warren. 2020. Save our education: Protect every child's right to learn in the COVID-19 response and recovery. London: Save the Children.

Zacharia, S. 2020. India (Telangana): Remote learning and village learning circles for disadvantaged students, Education continuity stories series. Paris: OECD Publishing.

The opinions expressed in this chapter are those of the author(s) and do not necessarily reflect the views of the Asian Development Bank, its Board of Directors, or the countries they represent.

Open Access This chapter is licensed under the terms of the Creative Commons Attribution-NonCommercial 3.0 IGO license (http://creativecommons.org/licenses/by-nc/3.0/igo/) which permits any noncommercial use, sharing, adaptation, distribution and reproduction in any medium or format, as long as you give appropriate credit to the Asian Development Bank, provide a link to the Creative Commons license and indicate if changes were made.

Any dispute related to the use of the works of the Asian Development Bank that cannot be settled amicably shall be submitted to arbitration pursuant to the UNCITRAL rules. The use of the Asian Development Bank's name for any purpose other than for attribution, and the use of the Asian Development Bank's logo, shall be subject to a separate written license agreement between the Asian Development Bank and the user and is not authorized as part of this CC-IGO license. Note that the link provided above includes additional terms and conditions of the license.

The images or other third party material in this chapter are included in the chapter's Creative Commons license, unless indicated otherwise in a credit line to the material. If material is not included in the chapter's Creative Commons license and your intended use is not permitted by statutory regulation or exceeds the permitted use, you will need to obtain permission directly from the copyright holder. 